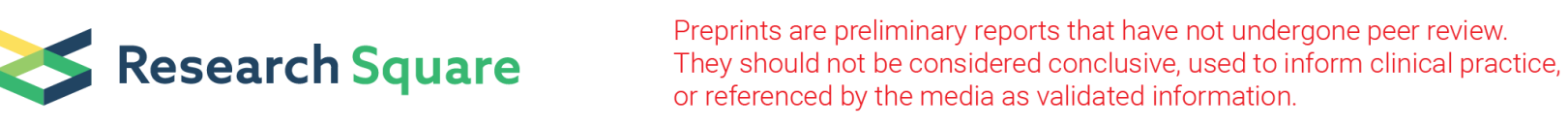

\title{
Assessing the Livelihood Strategies of Intensive Vegetable Farmers in the surge of Urbanisation in Kumasi Metropolis, Ghana
}

Frank Yeboah Adusei ( $\sim$ fyadusei@gmail.com )

Ministry of Food and Agriculture https://orcid.org/0000-0002-3942-4201

\section{Research Article}

Keywords: Intensive vegetable farming, livelihood, food security, urbanization, strategies, vegetable

Posted Date: May 5th, 2021

DOl: https://doi.org/10.21203/rs.3.rs-493293/v1

License: (1) (1) This work is licensed under a Creative Commons Attribution 4.0 International License.

Read Full License 


\section{Abstract}

Generally, the objective was to describe the livelihood strategies of intensive vegetable farmers in Kumasi Metropolis. The specific objectives were: to investigate the contributions made by intensive vegetable production, assess the livelihood strategies of the farmers and make new strategies for them to cope with the decreasing land size. The study used the case study technique for data collection. Checklists were used for data collection through semi-structured interviews. Ten participants were selected, eight farmers and two Agricultural Officers. The size of the participants was influenced by difficulty in getting farmers in the Kumasi metropolis. Besides, the intent was to become full with information on the topic at hand but not to maximize numbers. Descriptive and qualitative methods were used to present the primary data collected. The results showed that all the farmers interviewed were food secured. However, the main livelihood strategies employed by them were growing vegetables that are early maturing and investing in non-traditional animal rearing. It was evident that intensive vegetable farming provides fresh vegetables for a large segment of the urban population. It provides employment and income to a host of people including the farmers, marketers and urban poor as farm labourers which helps them to improve their food security status. Although livelihoods were primarily constrained by the loss of lands for residential purposes due to urbanization. It could be inferred that the significant features of farming as a food security strategy have not been fully understood by some stakeholders including policymakers.

\section{Introduction}

Ensuring food security for the urban population especially, for the household poor is a challenge mostly where rural food production is limited and where poor road infrastructure and storage facilities constrain rural-urban food movements. The rapid sprawling of cities in the Developing countries and Africa in specific and its related matters about rising levels of urban poverty and imminent food insecurity has positioned the issue of the production of food within metropolises as a key subject on the International Development Agenda (FAO, 2012). The potential values of growing food in the cities have already been discoursed by many Researchers. These includes to help low-income people access healthy food, foster cross-sector partnerships to improve the urban food policies and encourage knowledge about local food systems (Chase, 2012; Mayer and Knox, 2010; Zerbe, 2010; Hiranandani, 2010).

The peri-urban upsurge has brought accompanying myriad of socio-economic problems including unemployment, undernourishment, environmental degradation and a threat to food security (Maxwell et al., 2000). The volatile food prices, financial, economic and fuel prices make it uncertain for the urban poor. Urban consumers are almost totally dependent on food purchases and the most affected ones are the urban poor. This is because they are the first to lose their jobs and $60-80 \%$ of their income is spent on food, therefore these households suffer from both decreasing purchasing power and rising food prices. Children and women are the most vulnerable within these groups (FAO, 2009). In developing countries, farming in urban areas has become a common feature for a long time. The activity has helped the urban low-income dwellers to make a living. In spite of its significant and long history, urban agriculture (UA) receives considerably lesser recognition by authorities in the developing countries than in the developed 
world. Most recently, however, there is increasing need to sustainably manage UA in developing nations (FAO, 2007).

Urban sprawling and continuing increase in population are expected to add 2.5 billion people to the world's urban population by the year 2050 with nearly $90 \%$ of the increase are concentrated in Asia and Africa (UN, 2014). The high population density, rapid urban growth and high consumption rate of residents in metropolises has led to a wide range of local and global socio-economic and environmental impacts which requires attention from the world at large (Makinde, 2012). Continuing migration from rural to urban areas will expand the number of metropolises, and it acknowledges that urban centre is often plagued by food insecurity, environmental deterioration, crime and so forth (Ibid.). Nevertheless, rapid and unplanned urban growth as well as urban expansion threatens sustainable development and consumption patterns when the necessary infrastructure is not established or when policies are not well implemented (UN, 2014).

In recent years, urban agricultural practices have been studied from a wide range of different viewpoints. In a report by Levenston (2013), it was inferred that UA do not only provide more production opportunities for farmers, but also create more job opportunities for workers and improve social development in the localities themselves. In developing countries, the force of development in UA has also come from foodrelated problems, mainly: the lack of the guaranteed food security and the need for largescale food production. It is said that urban agriculture could help to improve both food intake and food quality (RUAF, 2015). With the world's cities growing rapidly, farming in urban areas needs to play a major role in feeding urban populations. In 2008, for the first time in history, about 3.3 billion people accounting for more than half of the world's populations were living in urban areas. This development, which directed the UN Secretary General, Kofi Annan to announce the "Urban Millennium" (UN-Habitat 2001), brings a significant challenge to emerging and exploding cities, not only in providing urban services, like shelter, water, energy and sanitation, but also in ensuring urban food security. The number of people expected to live in urban areas is predicted to be 5 billion by 2030 and particularly Sub-Saharan Africa would be experiencing one of the fastest rates of urbanization (UNFPA, 2007, UN-Habitat, 2008). Agriculture in Kumasi Metropolis however, has seen a dramatic transformation due to rapid urbanisation in the last twenty years. The agricultural land use has turn out to be less great than the demand for commercial, industrial and residential land use. Following this, it has been projected that about $80 \%$ of arable lands have been displaced for the construction of houses and other physical infrastructure. It is projected that $48 \%, 46 \%$ and $6 \%$ of Kumasi Metropolis are urban, peri-urban and rural respectively, which confirms the fast rate of urbanisation (KMA, 2006a).

The general objective of this research is to explore and describe the livelihood strategies of intensive vegetable farmers in Kumasi Metropolis as their land for farming is decreasing. In line with this, the specific objectives are to:

a. Assess the livelihood strategies of intensive vegetable farmers in Kumasi Metropolis.

b. Investigate the contribution of intensive vegetable production. 


\section{Research questions}

Main research question

Is intensive vegetable farming having the future of improving living conditions of urban farmers and what are their effective livelihood strategies with decreasing rate of arable land in Kumasi Metropolis?

\section{Sub-questions}

a. What are the effective strategies intensive vegetable farmers employed in the spate of increasing competition of arable land for other physical infrastructure?

b. Who are the actors involved in the input supply?

c. How is the produce marketed?

d. Is intensive vegetable production in Kumasi Metropolis profitable?

e. What is the state of living conditions of the intensive urban farmers?

Due to shortage of cold transport and storage facilities in Ghana (Obuobie et. al., 2006), perishable vegetables should be produced near the consumer in order to preserve its freshness. But owing to urbanisation, land needed to grow these vegetables are becoming scarce. And this is affecting the livelihood of the people involved. However, information is needed by the Ministry to adjust its activities. Simply put, to add to a public debate in Ghana and more globally to contribute to a better-informed decision-making and policy. The paper is structured into five sections. The section one above has presented the introduction. The section two presents the literature review whiles the section three describes the methodology used in this study. Section four discusses and analyses the results and finally the section five concludes.

\section{Literature Review}

To produce food, a person needs land and other resources like seeds and water. But to buy food a person needs money and access to market. The right to food therefore requires governments to provide the supporting environment in which people can use their full potential to produce or buy adequate food for themselves and their households (De Schutter, n.d.).

\section{Defining Food Security}

According to Ministry of Food and Agriculture (MoFA) (2007) food security is defined as good quality nutritive food, hygienically packaged and attractively presented, available in sufficient quantities throughout the year and can be found at appropriate places at reasonable prices. The key elements of the definition, as is compared with other definitions, are nutritive quality of food, self-sufficiency and physical availability. WHO (2000) also defined food security as giving populations both economic and physical access to a supply of food, sufficient in both quality and quantity, at all times, regardless of climate and 
yield, wages and social structure. However, World Food Summit (1996) defined food security as when all people, at all times, have physical and economic access to sufficient safe and nutritious food that meets their nutritional supply and food preferences for an active healthy life. The figure below shows the concept of food security as related to the topic at hand.

\section{Urban Agriculture concept}

Urban agriculture is not new phenomenon. For a very long time, humans have been raising animals and growing crops in an around urban areas since man started establishing themselves into long-term settlements. However, land use patterns, real estate speculation and emergence of food systems in the global economy have contributed to disregarding of farming in urban areas in the past. The UNDP reveals that in 1993 , just $15 \%$ of food consumed in urban areas worldwide was grown in inner-city. The number increased to $30 \%$ in the year 2005. That implies the share of urban food production doubled in over 10 years (Urban Farmer, 2012). In light of this, urban agriculture (UA) has emerged as one approach to contribute to local food security by increasing the availability and accessibility of fresh and healthy produce in food insecure areas in cities (FAO 2011; Martellozzo et al. 2014; Mack et al. 2017). This means finding ways to empower and support regenerative, biodiverse smallholder farms and local food systems should be prioritized in any discourse on sustainable agriculture and food security (FAO 2017).

The most remarkable feature of UA, which differentiates it from agriculture in the rural area, is that it is incorporated into the urban economic and ecological system. Such linkages include using of urban residents as labourers, using organic waste as fertilizer, urban wastewater for irrigation and direct links with urban consumers. It is also being part of the urban food system, competing for land with other urban activities which is also influenced by urban policies and plans (RUAF, n.d.). The comparative advantages of urban agriculture in relation to rural food production according to FAO (2007) explain that, its contribution is the highest for perishable, high added value commodities, example vegetables while rural areas supply the bulk of long-shelf staple food like cassava, maize and rice. As a result, they contribute directly to food security in urban areas.

Owing to the types and the challenges involved, UA has been defined in different ways. Mougeot (2000a) define UA: Urban agriculture is located within (intra-urban) or on the fringe (peri-urban) of a town, a city or metropolitan area and produces or raise, processes and distributes a diversity of food including non-food products which is (re)use by people within that urban area. Urban agriculture can also be defined succinctly as the cultivation of plants and the rearing of animals within and nearby cities (RUAF, n.d.).

\section{Actors involved in Urban Agriculture}

A large segment of people is involved in UA. They include suppliers of inputs (seeds, agrochemicals), labourers, transporters, processors, supermarkets, retailers and of course the urban farmers. These actors belong to either formal or informal economy (public or private sectors). Contrary to general belief, urban 
farmers are often not recent migrants who have moved from country side (rural) since the urban farmers need time to acquire urban land and other productive resources. In many cities, one will commonly also find low or mid-level government officials, civil/public servants involved in UA, as well as richer people who are seeking a good project for their capital. Women represent a significant part of urban farmers, since farming and its associated processing and selling activities, among others, can often be more easily combined with their household responsibilities (RUAF, n.d.).

\section{Importance of urban agriculture}

Household income can be supplemented through urban agriculture. Keeping of small livestock practiced by over a quarter of household, provides more than $60 \%$ of household cash income in Cairo. According to research by Drechsel et al. (2006), the net revenue per farm per year is between US $\$ 400$ and $\$ 800$ in Accra while in Kumasi the net revenue per farm per year is between $\$ 420$ and $\$ 1,920$ (Eriksen-Hamel and Danso, 2009). Thus, the aggregate benefits of UA to local economic development are significant. Although the contribution of UA to the Gross Domestic Product (GDP) may be small, its importance for certain commodities, such as vegetable production, might be substantial (Borne, Satornkich and Anwar, 2003; Nugent 2001). Recent research (Adeoti, Cofie and Oladele, 2012) carried out in Accra, Ghana shows that UA is vital for the survival of the urban poor. For many citizens, it is a paramount addition in the quest for improving urban food security. It has, therefore, become a vital element in the household survival strategies in the urban areas through the improvement of nutrition and the economic base of the households.

In Dar es Salaam, as reported by Mougeot (2000b), UA is the next largest employer after small traders. High-valued specialty foods for example, vegetables and non-food crops like flowers that require little space for producing are particularly good for providing desired cash income. But most of the urban farmers are poor and cultivate food mainly for their own use with little support or protection on small land that belong to someone else. Urban agriculture has helped improve the nutritional status of some households in Harare, Kampala and Nairobi. According to numerous surveys, women predominate in urban agriculture, which conveniently helps them to earn cash income, improve household diets, perform household chores, and exert greater control over household resources, budgets, and decision making (Ibid.).

\section{Challenges of urban agriculture}

Due to insufficient cold transport and storage, most of the perishable vegetables are produced in the cities or around the fringes. Urban agriculture can lift vulnerable groups out of poverty and can help to reclaim land and greening the city. Nevertheless, the poor farmers have many problems finding in and around the cities uncontaminated water sources for irrigation (Obuobie et al., 2006). 
Urban farmers may lack the knowledge and skills in production, processing and marketing that may bring about successful yields as well as income. Many people involved in UA do not own the land they use for production and they risk losing their job and investment when the land is taken for other purposes. In many developing countries, food production in urban areas is seasonal and not dependable as a yearround source of food security. And many urban residents have limited knowledge and access to equipment for preserving food that they grow. There are however, particular health challenges connected to UA, for example urban soils can be contaminated with heavy metals such as lead. Another concern is that there is little regulation about the use of pesticides and this may affect food safety. Much of this can be attributed to the widespread utilisation of unsustainable, intensive farming practices, such as the farming of high-yielding crops in monocultures with low genetic diversity and the use of excessive inputs of synthetic fertilisers and pesticides (Sánchez-Bayo and Wyckhuys 2019; Horton 2017).

Also, there is a concern about theft and vandalism by stray animals and human beings (CFSC, 2002). Other challenges are inappropriate irrigation system and financial assistance from Banks and other financial institutions are difficult to access due to insufficient collateral. From the studies conducted by RUAF (2007) in Kumasi Metropolis, marketing has been a main problem. This is because marketing is carried out by marketers (mainly women) who also regulate market prices. Nevertheless, there is no conclusive evidence from the literature that intensive vegetable farmers in Kumasi metropolis are readjusting their livelihood strategies to respond to decrease land size. This report would prove the necessity of assessing and research, especially with regards to economic and social effect of urban agriculture, to discover the important contributions that urban farming can have on maintaining sustainable social development.

\section{Methodology}

\section{The Study Area}

The study was conducted in Kumasi Metropolis, the capital city of Ashanti region. The city of Kumasi was established in the 1680's by King Osei Tutu I to function as the capital of Ashanti State. Given its strategic position and political power, Kumasi as a matter of progress, developed into a major commercial centre with all major trade itineraries converging on it. However, it came under the influence of British rule in 1890 . The city began to increase thereby making it the second largest only to Accra (which is the capital city of Ghana) in relation to land area, social life, population size and economic activity. Kumasi is situated in the transitional forest zone and its about $270 \mathrm{~km}$ north of the nation's capital, Accra. It is between latitude $6.35^{\circ}-6.40^{\circ}$ and longitude $1.30^{\circ}-1.35^{\circ}$, which ranges between $250-300$ metres in elevation above sea level and covers an area of about 254 square kilometres. The distinctive centrality of the city as a traversing place from all parts of country makes it a distinct point for many people to migrate to. The metropolitan area shares borders with Kwabre East District to the north, Atwima District to the west, Ejusu-Juaben Municipal to the east and Bosomtwi to the south. It's beautiful design and greenery has given it a compliment of being the "Garden city of West Africa". It covers about 90 suburbs, mainly as a result of the process and physical development (KMA, 2006b). According to Ghana's 
2010 Population and Housing Census, Ashanti region's share of population is 4,725,046 with 2,288,325 males and 2,436,721 females (GSS, 2011).

The Metropolis falls within the wet sub-equatorial type. The average humidity is around 84.16 per cent at sunrise and 60 per cent at sunset. The average minimum temperature is approximately 21.5 degrees Celsius and the maximum average temperature is about 30.7 degrees Celsius. The moderate temperature and humidity and the double maxima rainfall regime (214.3mm in June and $165.2 \mathrm{~mm}$ in September) have a direct effect on population growth and the environment as it has precipitated the influx of people from every part of the country and beyond its frontiers to the metropolis. The physical and natural environment is therefore an essential element or factor contributing to the socio-economic development of the Metropolis. This is chiefly because the climatic conditions are not harsh. Thus, Kumasi has become one of the most populous cities in Ghana (GSS, 2014).

\section{Research Design}

The research has qualitative approach based on two strategies; desk study and field research (case study). Desk study was done to obtain secondary data from journals, scientific books and proceedings of symposia, published reports and internet search. The secondary data generated helped to review literature and also provided a deep insight into primary data; both the empirical and theoretical base for data collection and analysis. To achieve the objectives and answer the questions, the study draws on the descriptive-analytical approach in assessing the livelihood strategies of intensive vegetable farmers in the surge of urbanisation in Kumasi Metropolis, Ghana.

\subsection{Field research (Sampling method)}

For the primary data collection, case study was used. Convenience sampling which is a type of nonprobability sampling was used. This was preferred since the researcher is not familiar with all the producing areas of intensive vegetable farming in Kumasi Metropolis. However, an interaction with Agricultural officer revealed the sites where decrease land size takes place. In order to have level playing field for all the areas, two farmers were randomly selected from each site to meet the criteria set.

\subsection{Sample size}

Qualitative research samples tend to be small in order to support the depth of case-oriented analysis that is fundamental to this mode of inquiry (Sandelowski, 1996). In addition, qualitative samples are mostly purposive or convenience, that is, selected by virtue of their capacity to provide richly-textured information, relevant to the phenomenon under study. In that regard, convenience sampling (Luborsky and Rubinstein, 1995; Marshall, 1996) as opposed to probability sampling employed in quantitative research - selects 'information-rich' cases (Patton, 1990). Qualitative research experts argue that there is 
no straightforward answer to the question of 'how many' and that sample size is dependent on a number of factors relating to epistemological, methodological and practical issues (Baker and Edwards, 2012). Sandelowski (1995) recommends that qualitative sample sizes are large enough to allow the unfolding of a 'new and richly textured understanding' of the phenomenon under study, but small enough so that the 'deep, case-oriented analysis' of qualitative data is not precluded. Morse (2000) proposes that the more useable data are collected from each person, the fewer participants are needed. She requests researchers to take into account parameters, such as the scope of study, the nature of topic (that is, complexity, accessibility), the quality of data, and the study design. Indeed, the level of structure of questions in qualitative interviewing has been found to influence the richness of data generated (Ogden, 2010), and so, requires attention; empirical research shows that open questions, which are asked later on in the interview, tend to produce richer data (Ibid.).

On this premise, 10 participants were selected and they were interviewed individually. The size was due to difficulties in getting urban farmers in the localities because of cosmopolitan nature of Kumasi Metropolis and also the researcher did not receive any funding. The selection of participants are as follows;

a. Eight (8) intensive urban farmers (2 from Georgia, 2 from Manhyia, 2 from Gyinyase and 2 from Kwame Nkrumah University of Science and Technology (KNUST) vegetable growing areas). These areas are major vegetable producing areas in Kumasi Metropolis.

b. Two (2) Agricultural officers from Metropolitan Agriculture Department (Technical officer and Municipal Director) as key informants. Data from these officers were needed to depict the general structure of Metropolitan farming and the government involvement.

The criteria for selection of urban farmers;

a. Those who were willing to take part in the interview.

b. Those who have farmed continuously for at least five (5) years. It is of the researcher's opinion that those who have farmed continuously for 5 years would have acquired substantial amount of experience due to more years spent. As a result, they also have emotional attachment to their job as their land is decreasing.

c. Those who rented the land and work on the land as well

d. Those who have experience in intensive vegetable production under decreased land size.

Criteria for selection of Agricultural extension officer;

a. Agricultural officer who works with the Metropolitan Agriculture Department and have worked with farmers for at least five (5) years.

b. An officer who has knowledge about UA. 


\subsection{Data collection}

The researcher used semi-structured interviews to collect primary data which took a form of open-ended questions to help induce further discussion. The issues covered were being designed in the checklist. The interview took a form of face-to-face with one participant at a time so as to collect data and learn about ideas, beliefs and activities. Semi-structured interviews involve pre-set questions, allowing for probing and explanation of answers. In this research, the title and the research questions were set and linked to the objective of the study, as the objective have to be achieved at the end of the study. The research questions were set out in two checklist guides that were used to gather data from the research participants, namely the eight (8) urban farmers and two (2) Agricultural officers in Kumasi Metropolis.

After developing the checklist, it was tested for its practicability to be used in a study and it was done through the process called pre-testing. Pre-testing involves developing a first version of a measure and asking people about their opinion before applying the final version in the study. This was done with two respondents who were not part of the actual research participants. It helped the researcher to form an opinion on the consequence of the questions to be used and aided in reviewing the checklist. In addition, direct observation and participation also form part of primary data collection. As a result, the researcher participated in vegetable bed preparation, transplanting, watering and weeding. Kumasi Metropolis is mostly Twi speaking and it is a language that the researcher is conversant with therefore for the participants who cannot speak English language interviews were conducted in the local language and translated to English. A voice recorder was used to ensure that data is not lost.

To avoid oversimplification and for validating raw data collected after carrying out the interviews, it was verified with four (4) farmers and one (1) officer for exactness. This was done after the main interview for clarification and to capture a clear understanding of views.

\section{Analysis of data}

Analysis simply means: What does the data say? Whereas interpretation also means: What does the data mean? Qualitative data collection through different qualitative methods are subject to narrative analysis. Analyzing qualitative data generally revolves around the interpretations and impressions of the researcher. For the reason that qualitative analysis depends on researchers' impressions and interpretations, it is important that its analysis also becomes systematic and that the researcher reports on his view in an organized and clear procedure. The researcher will pay attention to verbal statements, context, coherence and contradictions of opinions, rate of recurrence and volume of remarks as well as developing themes and trends. Grbich (2007), proposes that there are two main types of narrative analysis: the socio-linguistics, which is concerned with conveyed meaning and the socio-cultural, which investigates the framework of people's responses in a particular incident. These two types of analysis would be used in this study. 


\section{Results And Discussion}

From the reviewed literature so far, it could be deduced that the UA has become a reality and vital source of food security and income which needs to be acknowledged and supported, especially in an era of growing global food insecurity and rapid urban sprawl. The Metropolitan Director has worked with farmers for 24 years while the Technical officer has 17 years' experience. It was difficult for the officers to quantify the land size used solely for intensive urban farming alone. The Agricultural Officers cited that; from the past fifteen years the number of farmers has decreased from 17,583 to 5,086 spread over the Metropolis. From experience, the number of farmers and even the land size has reduced and continues to decrease almost every year causing many people to lose their jobs. The decrease of the land is an autonomous development to MoFA's activities. These developments have affected the Ministry to also train the farmers on non-traditional farming (grasscutter, snail, rabbit and mushroom production). This will help farmers to earn some extra income apart from their vegetable production. MoFA's duty is to facilitate technology transfer and also provide credit in the form of farm inputs. With this in mind, MoFA has assigned field officers to the farmers who organises training, seminars, and field demonstration. From the field study, the researcher asserts that there is an absence of coordination between the relevant stakeholders to work together to address problems related to decrease of land in the study area.

Some farmers have specialised in growing exotic vegetables like lettuce, cabbage, spring onion and cauliflower since they started while others grow both local and exotic vegetables. They are named exotic because they represent a group of vegetables unlike standard tomatoes, pepper and okra and the viable seeds of exotic vegetables are imported but cannot be produced in Ghana.

The Kumasi Metropolitan Assembly (KMA) and traditional leaders are the main facility providers with responsibility and obligation to make available open spaces where farming could be done on long term basis but these services are lacking. Several attempts had been made by farmers to petition the Metropolitan authorities to make land available for long-term but this is proving to be futile. Effective action to alleviate the problem is proving to be uncertain as described by the farmers and the Agricultural officers due to competition of land for housing development. Most of the farmers interviewed (75\%) together with the 2 Agricultural Officers mentioned that access to and land security in particular, is most important issue than availability as such. There are sufficient undeveloped or underutilized land available, often access to them is fiercely disputed. Farmers gain access to land from a diverse stakeholder, through various modalities of tenure arrangements which are very often informal and mostly based on customary law.

Farming in the study area was found to have relatively low barriers to entry and exit due to few costeffective farm inputs like hoe, cutlass, watering can used. It does not require relatively large capital. Observation, participation and discussion with the farmers' discovered that farming activities are labourintensive. Because of the laborious nature of UA in Kumasi metropolis, men usually dominate most of the activities (production). This disputes the report by Mougeot. There is low number of farmer group and as 
a result they have limited capacity to lobby for large land size with long term tenure. The farmers are not doing badly at all looking at the circumstances they are going through.

The key stakeholders are Ministry of Food and Agriculture, Kumasi Metropolitan Assembly, Kwame Nkrumah University of Science and Technology, Centre for National Culture, marketers, traditional authorities, input dealers, individual land owners and NGO's. The MoFA's support to the farmers is training (transfer of technology) and supplying/selling of subsidized inputs (fertilizers, seeds and farm machinery). Land is assigned by various bodies including traditional authorities, individual land owners and other governmental bodies like Management Development and Productivity Institute. The farmers are solely responsible for arranging for land through negotiation with land owners to rent. In this case, they become temporary users and cannot invest or plan for long term on the land. As of now, all the land used by the farmers is rented and at any point in time they could be driven out.

In the past, marketing of vegetables was done by women who come from various part of the country (Accra, Takoradi, Sunyani and from Kumasi). The women marketers buy the vegetables in bulk and sell to retailers. The retailers then sell to the final consumers at market centres and also by hawking in the streets or from house to house. Some of the factors hindering intensive urban farming as told by farmers and the Officers were:

i. Land is dwindling because of urbanisation.

ii. Farmers find it difficult to develop or invest in the land as they are temporary land holders.

iii. In some places it is difficult to get water, especially in the dry season period.

iv. It is the marketers who dictates the prices for the farmers.

v. Lack of cold storage facilities (vegetables get rotten during period of glut).

vi. Some of the youth are not interested in farming (There is a common perception by the youth that farming is seen to provide low wages and thus an employer of the last resort).

With the help of MoFA, the farmers have already acquired knowledge, skills and farm inputs. Prices for their produce has not been the best, sometimes due to poor storage facilities. It is believed that, if the right structures are put in place, exporting of vegetables is even possible.

The net revenue per farm per year in the study area is between US $\$ 1,300$ and 2,800 . This supports the report by Eriksen-Hamel and Danso (2009). Mougeot (2000) inferred that most of the urban farmers in Dar es Salaam are poor and cultivate food mainly for their own use. On the contrary, the study found that $75 \%$ of intensive urban farmers depend solely on UA for their livelihood and the amounts quoted by the farmers suggest that they are not poor. Some $63 \%$ of farmers were forced into UA due to lack of job opportunity or economic stress. Notwithstanding, all the participants are now food secured and can meet their basic needs. These concerns underscore the significance of UA as a viable alternative to economic crises for farmers as their living conditions has been raised. Another striking finding from the study was the reality that UA is a significant provider of employment. In total, all the farmers interviewed had employed 24 people and the farmers have been engaged in UA spanning between 6-20 years. Therefore, 
urban agriculture has contributed greatly to economic empowerment, food security and making available fresh vegetables.

The livelihood strategies employed by the farmers to respond to the pressures on the land includes growing short-cycled crops such as lettuce which does not only bring quick income but also to safeguard against loss of investment should the land be sold. Market driven production is also carried out in order for the farmers to recover their investment. Some farmers have diversified their activities to include trading of consumable goods. Poultry manure is mostly used instead of chemical fertilizer to reduce cost of production and also to make utilisation of sustainable intensive farming practices as opposed to reports by Sánchez-Bayo and Wyckhuys (2019) and Horton (2017). Currently, all the participants practice intensive growing techniques by rotating the crops on the same plot over the years but the land is not allowed to fallow, not even for a month. In all the areas studied, farmers learn from each other which help them to improve their production. Diversification into livestock production in relatively far communities was also discovered with some farmers. The pooling together of resources to buy inputs, such as irrigation machinery has been an effective way of reducing cost and risk as was observed at Gyinyase farmers group. The table below show the biodata of the participants.

Biodata of participants

\begin{tabular}{c|c|l|l|l|l|l|l|}
\hline seudonym & $\begin{array}{l}\text { Age } \\
\text { (years) }\end{array}$ & $\begin{array}{l}\text { Marital } \\
\text { status }\end{array}$ & $\begin{array}{l}\text { Family } \\
\text { size }\end{array}$ & $\begin{array}{l}\text { Years in } \\
\text { production }\end{array}$ & Sex & Educational level & $\begin{array}{l}\text { Site of intensive } \\
\text { vegetable farm }\end{array}$ \\
\hline A & 47 & Widower & 3 & 15 & Male & $\begin{array}{l}\text { Diploma in } \\
\text { Theology }\end{array}$ & Hotel Georgia \\
\hline B & 28 & Single & 1 & 6 & Male & $\begin{array}{l}\text { HND in Chemical } \\
\text { Engineering }\end{array}$ & Hotel Georgia \\
\hline C & 42 & Married & 2 & 6 & Male & $\begin{array}{l}\text { Vocational training } \\
\text { in carpentry }\end{array}$ & Manhyia \\
\hline D & 50 & Married & 4 & 12 & Male & Primary & Manhyia \\
\hline E & 45 & Married & 3 & 7 & Female & Middle school & Gyinyase \\
\hline F & 37 & Married & 8 & 12 & Male & $\begin{array}{l}\text { Polytechnic } \\
\text { (division 2) }\end{array}$ & Gyinyase \\
\hline G & 25 & Single & 1 & 5 & Male & $\begin{array}{l}\text { Junior High } \\
\text { Secondary school }\end{array}$ & KNUST \\
\hline H & 39 & Married & 2 & 7 & Male & $\begin{array}{l}\text { Ordinary level } \\
\text { KNUST }\end{array}$ \\
\hline
\end{tabular}

Source: Primary data from the field

\section{Conclusions}

Kumasi Metropolis is increasing in size in terms of population with fast physical infrastructure and this has caused the decrease of land for farming. From the results, it could be inferred that intensive urban farming alone may not be able to provide all the vegetable need of Kumasi Metropolis, but it positively has the potential to be an important driving force in improving economic prospects and addressing food 
security fears. As of now, the practice remains generally unrecognised, mostly unassisted and every so often not favoured as the farming land is being used for other physical infrastructure. It could be deduced that the future of intensive vegetable farming is not optimistic in the Metropolis if the situation continues as the farmers are not sure about their land security.

To ensure sustainable UA in Kumasi metropolis, all stakeholders need to pay closer attention to its potentials. While the researcher holds the view that its current value has been overstated; its role can be enhanced through a range of strategic interventions including;

a. Strengthening market chains, principally through the creation of farmers' markets and in quest of access into formal supermarket / retail networks thereby helping to provide better market access to UA farmers.

b. Providing advice on sales, marketing, processing and preserving vegetables is needed.

c. A lack of land tenure security is regarded as a particular challenge which has forced people to farm on marginal and undesirable land. A clear argument exists to legitimise land access and to give some degree of security of tenure to encourage confidence among the producers and to reduce their fears and resultant lack of investment in what is often seen as land which they have limited access to.

d. Urban planners need to allow for an incorporation of UA activities, for example, in Mozambique (Maputo) 'green zones' have been provided in the city for agricultural activities (FAO, 2012).

e. Ensuring access to safe and reliable water supplies is a key.

f. Increasing production and improving quality of produce (through training, recycling and use of less harmful inputs).

g. Continued encouragement of the positive actions of the Ministry of Food and Agriculture, these include extension support. This should take the form of advice about matters such as water harvesting, composting, nutritional crop knowledge, contamination management, UA business development and the distribution of quality seeds and agrochemicals.

h. Encouraging local stakeholder forums which network key providers and farmers in the field and which can lobby local government and initiate self-actions to support UA activities.

i. Links between the NGO's, Metropolitan, Municipal Assemblies and Ministry of Food and Agriculture all other stakeholders must be strengthened to better service the needs of UA farmers.

j. Local awareness of the key role which UA can and does play in urban food security and what support is available locally is essential.

\section{Declarations}

Funding: This study received no specific financial support. 
Competing Interests: The author declares that he has no conflict of interests.

Transparency: The author confirms that the manuscript is an honest, accurate, and transparent account of the study was reported; that no vital features of the study have been omitted.

Ethical approval and consent to participate: This study follows all ethical practices during writing. Consent to participate was obtained from each respondent.

Acknowledgements: I wish to thank all the farmers who participated.

Consent for publication: The author agrees and consent for the article to be published.

Data Availability: Participants of this study did not agree for their data to be shared publicly, so supporting data is not available.

\section{References}

Adeoti, A. I., Cofie, O. and Oladele, O.I., (2012) Gender Analysis of the Contribution of Urban Agriculture to Sustainable Livelihoods in Accra, Ghana, Journal of Sustainable Agriculture, 36:2, 236-248.

Baker, S.E and Edwards R, (2012). How Many Qualitative Interviews is Enough? Expert Voices and Early Career Reflections on Sampling and Cases in Qualitative Research. National Centre for Research Methods Review Paper. http://eprints.ncrm.ac.uk/2273/4/how_many_interviews.pdf

Borne, F., Satornkich, J.P. and Anwar, S.M (2003). Plant Modelling for Landscape Changes Visualization: Application to a Peri-Urban Agricultural Area. In Proceedings of the International Symposium on Plant Growth Modelling, Simulation, Visualization and Their Applications PMA03 Conference, Beijing, China.

Chase, K. L. (2012). From Hometown to Growtown: A Study of Permaculture-Based Neighbourhood Revitalization Strategies for Muncie, Indiana (Thesis). Ball State University, Muncie, Indiana. 
Community Food Security Coalition (2002) Urban Agriculture and Community Food Safety in The United States: Farming from the City Centre to the Urban Fringe. www.foodsecurity.org/urbanagpaper.pdf

De Schutter, O., (n.d). United Nations Special Rapporteur on the right to Food. www.srfood.org/index.php/en/right-to-food

Drechsel P, Graefe S, Sonou M, Cofie 0.0 (2006). Informal irrigation in urban West Africa: An overview. Colombo, Sri Lanka: International Water Management Institute (IWMI Research Report 102), pp. 1-43.

Eriksen-Hamel N.S., Danso G., (2009). Urban Compost: A Socio-Economic and Agronomic Evaluation in Kumasi, Ghana, in: Redwood M., (ed.) Agriculture in Urban Planning, Generating Livelihoods and Food Security. Earthscan, London.

Food and Agriculture Organisation (2007). Profitability and Sustainability of Urban and Peri-Urban Agriculture. Agricultural Management, Marketing and Finance Occasional Paper, Number 19. ftp://ftp.fao.org/docrep/fao/010/a1471e/a1471e00.pdf

Food and Agriculture Organisation (2009). Follow-up to The High-Level Conference on World Food Security: FAO Contribution to The Implementation of The Comprehensive Framework for Action, Document for FAO Council $136^{\text {th }}$ session, 15-19 June, Rome.

Food and Agriculture Organisation (2011). The Place of Urban and Peri-urban Agriculture (UPA) in National Food Security Programmes. FAO, Rome.

Food and Agricultural Organization, (2012). Growing Greener Cities in Africa, FAO: Rome. 
Food and Agriculture Organisation (2017). The State of Food and Agriculture. Leveraging Food Systems for Inclusive Rural Transformation. FAO, Rome

Ghana Statistical Service (2011). 2010 Population and Housing Census. www.ghana.gov.gh/census/phc2010.pdf

Ghana Statistical Service (2014). 2010 Population and Housing Census, Kumasi Metropolitan Analytical Report. GSS, Accra.

Grbich, C. (2007). Qualitative Data Analysis - An Introduction. London/Thousand Oaks/New Delhi: Sage Publications.

Hiranandani, V. (2010). Sustainable agriculture in Canada and Cuba: A comparison. Environmental Development and Sustainability, 12(5), 763-775. doi:10.1007/s10668-009-9223

Horton, P. (2017). We Need Radical Change in How we Produce and Consume Food. Food Security 9:1323- 1327. doi: 10.1007/s12571-017-0740-9

Kumasi Metropolitan Assembly (2006a). www.kma.ghanadistricts.gov.gh/?arrow=atd\&=6\&sa $=5475$

Kumasi Metropolitan Assembly (2006b) Kumasi Township. www.kma.ghanadistricts.gov.gh

Levenston, M., (2013). Netherlands's Report: Urban agriculture beneficial to society. http://www.cityfarmer.info/2013/10/09/netherlandss-report-urban-agriculture-beneficialto-society

Luborsky, M.R, and Rubinstein, R.L. (1995). Sampling in Qualitative Research: Rationale, Issues. and Methods Res Aging;17(1):89-113. 
Mack, E.A, Tong, D., and Credit, K. (2017). Gardening in the Desert: A Spatial Optimization Approach to Locating Gardens in Rapidly Expanding Urban Environments. International Journal of Health Geographics. doi: 10.1186/s12942-017-0110-z

Makinde, O. O. (2012). Urbanization, Housing and Environment: Megacities of Africa. International Journal of Development and Sustainability. Vol. 1 No.3.

Marshall, M.N, (1996). Sampling for Qualitative Research. Fam Pract:;13(6):522-6.

Martellozzo, F., Landry J.S., and Plouffe D. (2014). Urban Agriculture: A Global Analysis of the Space Constraint to Meet Urban Vegetable Demand. Environmental Research Letters. doi: 10.1088/17489326/9/6/064025

Maxwell, D. et al., (2000). Urban Livelihoods and Food and Nutrition Security in Greater Accra, Ghana. Research Report 112, International Food Policy Research Institute, Washington, D.C.

Mayer, H., \& Knox, P. (2010). Small-Town Sustainability: Prospects in the Second Modernity. European Planning Studies, 18(1), 1546-1568. doi:10.1080/09654313.2010.504336

Ministry of Food and Agriculture (2007). Food and Agriculture Sector Development Policy (FASDEP II). Accra: Ghana.

Morse, J.M, (2000). Determining Sample Size. Qualitative Health Research;10(1):3-5.

Mougeot, L.J.A. (2000a). Urban Agriculture: Definition, Presence, Potentials and Risks. In: Bakker, N., Dubbeling, M., Guendel, S., Koschella U. S., H. de Zeeuw (ed.). 2000. Growing Cities, Growing Food, Urban Agriculture on the Policy Agenda. DSE Germany, 1-42. 
Mougeot, L.J.A. (2000b). Achieving Urban Food and Nutrition Security in the Developing World: The hidden Significance of Urban Agriculture. IFPRI, 2020 Focus 3. Brief 6 of 10. Washington, D.C.

Nugent, R.A (2001) Using economic Analysis to Measure the Sustainability of Urban and Peri Urban Agriculture: A Comparison of Cost-Benefit and Contingent Valuation Analyses. In Proceedings of the CIPSUIPA and ETC-RUAF Workshop on Appropriate Methodology in Urban Agriculture Research, Planning, Implementation and Evaluation, Nairobi, Kenya.

Obuobie, E. et al., (2006) Irrigated Urban Vegetable Production in Ghana: Characteristics, Benefits and Risk. City Farmer, Canada. www.cityfarmer.org/GhanalrrigateVegis.html

Ogden, J., and Cornwell, D, (2010). The Role of Topic, Interviewee, and Question in Predicting Rich Interview data in the field of health research. Sociology Health IIIn.;32(7):1059-71.

Patton, M.Q, (1990). Qualitative Evaluation and Research Methods. 2nd ed. Newbury Park, CA: Sage.

RUAF (n.d). What is Urban Agriculture. www.ruaf.org/node/512

RUAF (2007) Gyinyase Organic Vegetable Growers' Association in Kumasi, Ghana. www.ruaf.org/sites/default/files/uam17_article15.pdf

RUAF (2015). Urban Agriculture: What and Why? http://www.ruaf.org/urban-agriculture-what-and-why

Sánchez-Bayo, F. and Wyckhuys K.A.G. (2019). Worldwide Decline of the Entomofauna: A Review of its Drivers. Biological Conservation 232:8-27. doi: 10.1016/j.biocon.2019.01.020 
Sandelowski, M, (1995). Sample Size in Qualitative Research. Research in Nursing and Health; 18(2):179-83.

Sandelowski, M. (1996). One is the Liveliest Number: The Case Orientation of Qualitative Research. Research in Nursing and Health;19(6):525-9.

United Nation (2014). World Urbanization Prospects. The 2014 Revision.

UNFPA (2007). The State of the World Population. United Nations Population Fund, New York. www.unfpa.org/swp/2007/presskit/pdf/sowp2007_eng.pdf

UN-Habitat (2001). Cities in a Globalizing World. Global Report on Human Settlements 2001. UNCHS, London: Earthscan Publications.

UN-Habitat (2008) State of the World's Cities 2008/2009, Harmonious Cities, Earthscan, London.

Urban Farmer (2012). Urban Agriculture. http://theurbanfarmer.ca/resources/urban-agriculture/

World Bank (2008). World Development Report 2008: Agriculture for Development. http://siteresources.worldbank.org/INTWDR2008/Resources/WDR_00_book.pdf >

World Food Summit (1996) An Introduction to the Basic Concepts of Food Security. www.fao.org/docrep/013/al936e/al936e00.pdf

World Health Organisation (2000) Food and Nutrition Action Plan, WHO Europe, Copenhagen. 
Zerbe, N. (2010). Moving from Bread and Water to Milk and Honey: Framing the Emergent Alternative Food Systems. Humboldt Journal of Social Relations, 33(1/2), 4-30.

\section{Figures}

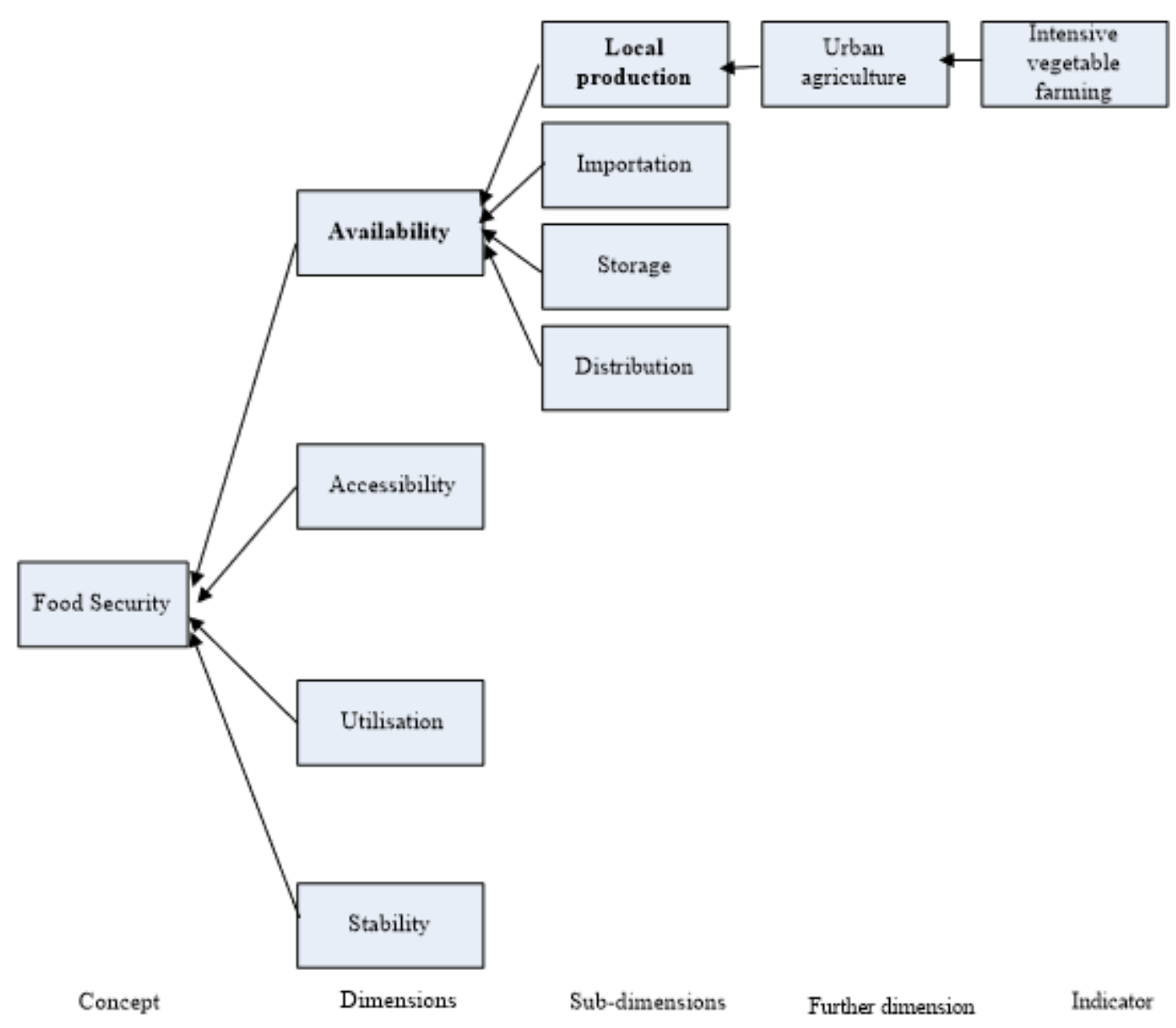

\section{Figure 1}

Food Security concept. Source: Author's construct, 2020 